\title{
Natural Agents that Act in the Prevention and Treatment of Oral Mucositis: Literature Review
}

\section{Agentes Naturais que Atuam na Prevenção e Tratamento da Mucosite Oral: Revisão de Literatura}

\author{
Tamires Ribeiro Avelino*a; Ana Carla Barletta Sanches ${ }^{\mathrm{b}}$; Tila Fortuna Costa Freire ${ }^{\mathrm{b}}$; Gabriela Botelho Martins ${ }^{\mathrm{c}}$; \\ Juliana Borges de Lima Dantas ${ }^{\mathrm{b}}$
}

${ }^{a}$ Centro Universitário Regional do Brasil, Dentistry Course. BA, Brazil.

${ }^{b}$ Federal University of Bahia, Institute of Health Sciences, Stricto Sensu Post-Graduate Program in Interactive Processes of Organs and Systems, BA, Brazil. 'Institute of Health Sciences of the Federal University of Bahia. BA, Brazil

*E-mail: tamyribeyro@hotmail.com.

Recebido em: 30/06/2020

Aprovado em: 17/11/2020

\begin{abstract}
Oral mucositis $(\mathrm{OM})$ is one of the most frequent and painful problems caused by head and neck radiotherapy and/or chemotherapy. Because there is no gold standard therapy for this disruptive conditions management, the therapeutic approach promotes palliative action, which consists of the signs and symptoms relief, in addition to preventing further complications. The present study aims to identify the main natural agents that act in the prevention and treatment of $\mathrm{MO}$, as well as to describe the pathophysiology and classification of this condition. This is a literature review of qualitative and exploratory nature through survey of scientific articles in the database SciELO, Lilacs, Medline and Pubmed. The results demonstrated that chamomile, propolis, aloe and honey have been widely used in dentistry, being pointed out in the scientific literature as promising strategies, as they present analgesic and anti-inflammatory effects, besides being well tolerated by the patients and have a low cost. It can be considered that the use of these agents for the prevention and treatment of OM provides a clinical lesions improvement, with consequent advance in the quality of life of these patients. However, more studies need to be carried out in an attempt to obtain more information about the most appropriate posology and presentation form, besides evaluating the toxicity of these natural agents.
\end{abstract}

Keywords: Stomatitis. Chamomile. Propolis. Aloe. Honey.

\section{Resumo}

A mucosite oral (MO) consiste em um dos problemas mais frequentes e dolorosos provocados pela radioterapia em região de cabeça e pescoço elou quimioterapia. Por não existir terapia considerada padrão ouro para o manejo desta condição perturbadora, a abordagem terapêutica promove ação paliativa, que consiste no alivio de sinais e sintomas, além de prevenir maiores complicações. O presente estudo teve como objetivo identificar os principais agentes naturais que atuam na prevenção e tratamento da MO, bem como descrever a fisiopatologia e classificação desta afecção. Trata-se de uma revisão de literatura de natureza qualitativa e exploratória através de levantamento de artigos cientificos na base de dados SciELO, Lilacs, Medline e Pubmed. Os resultados demonstraram que a camomila, a aloe vera, a própolis e o mel têm sido amplamente utilizados na Odontologia,sendo apontados na literatura científica como estratégias de tratamento promissoras, pois apresentam efeito analgésico e antiinflamatório, além de serem bem tolerados pelos pacientes e possuirem baixo custo.Pode-se considerar que a utilização desses agentes para a prevenção e o tratamento da MO proporciona uma melhora clínica das lesões, com conseqüente melhora na qualidade de vida desses pacientes. Todavia, mais estudos precisam ser realizados na tentativa de se obter maiores informações acerca da posologia e forma de apresentação mais indicadas, além de avaliar a toxicidade desses agentes naturais.

Palavras-chave: Estomatite. Camomila. Própolis. Aloe. Mel.

\section{Introduction}

Oncologic treatment causes disorders that are capable of destabilizing the integrity of the oral cavity of the person affected by cancer. Patients submitted to antineoplastic therapy may develop oral mucositis (OM), which increases the vulnerability to the installation of opportunistic infections, in a way to affect the patient's feeding, oral hygiene and communication capacity, in addition to increasing the risk of installing a bacteremia or sepsis ${ }^{1}$.

Regarding OM, this is an acute clinical problem that is difficult to manage. It constitutes an inflammatory response of the mucosa to the chemotherapy and/or radiotherapy action in head and neck regions, administered for the treatment of malignant neoplasia. Clinically, it is characterized by hyperemia, edema, ulceration, pain, and in more severe cases, hemorrhage and secondary infection. It is worth pointing out that this condition represents a serious and frequent problem that occurs during oncologic treatment, and that preventive management is capable of significantly reducing this side effect $^{2,3}$

Risk factors for the OM evolution are diverse, with emphasis on unsatisfactory oral hygiene conditions; oral cavity infections; smoking and alcoholism; immune response deficiency associated with immunosuppression; local trauma, which may be caused by inadequate brushing, use of poorly adapted dentures or orthodontic devices; intake of foods with high temperature and with excess condiments; use 
of substances that cause hyposalization, with consequent reduction of the local defense capacity; affected irradiation site and type of chemotherapy administered ${ }^{4}$.

The degree of involvement of OM can be measured by means of oral toxicity measurement scales. The items analyzed for mucositis staging include signs and symptoms, such as erythema and ulcers, local pain, swallowing difficulty and modified diet need ${ }^{1}$.

The therapeutic approach to this condition is based mainly on palliative and preventive management, in which therapy should be carried out with a view to preventing the evolution of tissue irritation and damage to the cells that make up the oral mucosa. In conjunction with the available treatments, it is important to follow up strict oral hygiene measures, as well as a diet appropriate to the oncologic patient ${ }^{5}$.

The OM management is dependent on the severity level. Currently, it is suggested that analgesics, anti-inflammatory drugs, cryotherapy and laser therapy be used with low -power laser ${ }^{6,7}$. Besides the conventional treatments used for the prevention and treatment of $\mathrm{OM}$, there is also the use of medicines based on natural agents. A classic example used in the healing process is the flavonoid compounds, which have the ability to interfere in the functional cells properties, such as mast cells, basophils, lymphocytes and platelets. In addition, these compounds present anti-inflammatory, analgesic and antimicrobial activities. In addition, the natural agents have broad acceptance, since they present low cost, induce tissue repair and offer low toxicity or interaction with other drugs ${ }^{8}$.

In view of the above, the objective of the present study was to identify in the literature natural agents that act in the prevention and treatment of chemo and radio induced OM.

\section{Development}

\subsection{Methodology}

It was a research and compilation of scientific articles characterized as a narrative literature review. It has a qualitative and exploratory nature.

The review was carried out by means of a retrospective survey in the period between 2009 and 2019, with the implementation of two classic articles from the years 1979 and 1999, which present extreme relevance to the proposed theme, since they address the main graduation scales of OM. The study was based on articles collected in the main electronic bases, SciELO, Lilacs, Medline and PubMed.

To perform the search, the following keywords were crosschecked according to the Descriptors Decs: "mucosite oral" and "oral mucositis", "agentes naturais" and "natural agents", "aloe vera" and "aloe vera", "camomila" and "chamomile", "mel" and "honey", "própolis" and "propolis", backed up by the Boolean operator AND/OR. The following inclusion criteria were used: papers published in the period mentioned above that included the themes discussed; works that did not have conflicts of interest, in Portuguese and English.
According to the search adopted, a total of 907 articles were found. Of these, 849 studies were excluded because they did not meet the established criteria. A total of 39 scientific papers, of which 36 are current articles, two classic articles that addressed classical scales of MO graduation, and a doctoral thesis, were selected for the present study, according to the inclusion criteria.

\subsection{Oral mucositis}

OM consists of inflammation affecting any region of the oral cavity lining mucosa, caused by chemotherapeutic cytotoxicity and/or irradiation in head and neck region, which may result in the oncologic therapy limitation, since it is configured as an entry port for pathogen microorganisms and makes it difficult the patient's feeding and hydration ${ }^{9}$. Among the risk factors that are associated with the onset of such clinical signs, one can include the radiation site, preexistence of dental disease, unsatisfactory oral hygiene, reduction in saliva production, high level of immune system impairment and the existence of local infection at the irradiation site ${ }^{10}$.

Sonis ${ }^{11}$, points out that after locoregional radiotherapy and/ or chemotherapy were administered, tissues are affected in a way that initiates the first phase of the lesion, through cellular destruction at the DNA level. This damage can promote attack on cells lining the basal epithelium and submucosa. They can also act indirectly through the formation of reactive oxygen species (ROS). Although the mucosa may appear normal in this initial phase, the cascade of events initiated will cause the mucosa gradual destruction.

Concerning the radio-induced OM, it is manifested in the second week of radiotherapy treatment and affects mainly the mucosa that makes up the radiation site, and tends to disappear gradually between 2 and 3 weeks after the treatment completion $^{12}$. When it comes to chemo-induced OM, this type of affection usually occurs in the first week of infusion, and depends on the type of chemotherapy used. In addition, chemotherapeutic-induced mucositis has a greater affinity for non-keratinized oral surfaces, such as the jugal mucosa, ventrolateral surface of the tongue, soft palate and mouth floor, since they are regions that present lower mitotic activity ${ }^{13}$.

Among the signs and symptoms of OM, the main ones are erythema, cleft lip, edema, hemorrhagic conditions and painful ulcers. Additionally, the patient may experience partial or total taste loss, which are called dysphagia and ageusia, local or systemic infectious conditions, malnutrition and disorders that decrease the quality of life in the short and long term of the patient ${ }^{14}$.

The degree of involvement of $\mathrm{OM}$ can be measured by means of oral toxicity measurement scales. The items analyzed for mucositis staging are: erythema and ulcers, local pain, deglutition difficulty and the need for a liquid or parenteral diet. According to the World Health Organization - $\mathrm{WHO}^{15}$, OM can be classified in 4 degrees: degree 0 , 
represents the absence of signs or symptoms; in grade 1, the mucosa is erythematous and painful; degree 2 is characterized by the presence of ulcers; however, the patient feeds normally; in degree 3 , in addition to ulcers, the patient can only maintain a liquid diet; and the last degree, represented by 4 , the patient cannot be fed, with the need for parenteral/enteral diet, as demonstrated by Table 1 .

According to the scale of measurement of the "National Cancer Institute" (Instituto Nacional do Cancer - NCI ${ }^{16}, \mathrm{OM}$ can be graduated according to signs, symptoms and function. This scale presents five scores, where degree 0 represents the absence of oral cavity alteration; degree 1 is identified with erythematous areas in the mucosa and the patient reports minimal symptoms and solid feeding; degree 2 is characterized by the presence of areas with pseudo membranes associated with ulcers and the patient reports pain and modified diet; degree 3 is marked by the presence of confluent ulcers, pseudo membranes and bleeding to light trauma, in addition to the painful sensation of not allowing oral feeding; in degree 4, the patient manifests spontaneous necrosis and bleeding, followed by degree 5 , in which there is a risk of death. The patient bearing OM must be carefully evaluated so that the degree of toxicity is known as well as the correct treatment.

Table 1 - Comparison among the WHO and NCI oral mucositis scales

\begin{tabular}{|c|c|c|c|c|c|c|}
\hline & Degree 0 & Degree 1 & Degree 2 & Degree 3 & Degree 4 & Degree 5 \\
\hline $\begin{array}{c}\text { WHO } \\
\text { Scale }\end{array}$ & $\begin{array}{c}\text { Absence of } \\
\text { signs and } \\
\text { symptoms }\end{array}$ & $\begin{array}{c}\text { Erythema } \\
\text { and painful } \\
\text { symptomatology }\end{array}$ & $\begin{array}{c}\text { Painful } \\
\text { Ulcers, } \\
\text { enable solid and } \\
\text { liquid feeding }\end{array}$ & $\begin{array}{l}\text { Ulcers, ingesting } \\
\text { liquids is the } \\
\text { only possibility }\end{array}$ & $\begin{array}{l}\text { Parenteral/ } \\
\text { enteral } \\
\text { nutrition }\end{array}$ & - \\
\hline $\begin{array}{c}\text { NCI } \\
\text { Scale }\end{array}$ & $\begin{array}{c}\text { Intact } \\
\text { Mucosa }\end{array}$ & Erythema & $\begin{array}{c}\text { Ulcers or } \\
\text { irregular pseudo- } \\
\text { membranes }\end{array}$ & $\begin{array}{c}\text { Ulcers with } \\
\text { bleeding } \\
\text { to small traumas }\end{array}$ & $\begin{array}{c}\text { Ulcers with } \\
\text { spontaneous } \\
\text { bleeding and } \\
\text { necrosis }\end{array}$ & Death \\
\hline
\end{tabular}

Source: Research data.

\subsection{Natural agents acting in the prevention and treatment of $\mathrm{OM}$}

OM management is very important for improving nutritional status, hydration and quality of life of patients affected by this condition, and that both prevention and control are essential for the good prognosis in neoplasia, since this condition may be able to limit or cause treatment interruption, in a way that it affects the tumor control ${ }^{17,18}$.

Regarding the OM management, despite several studies, there is still no gold standard therapy for the management of this condition. Figueiredo et al. ${ }^{1}$, Centurion et al. ${ }^{18}$ and Lalla et al. ${ }^{19}$, suggest the use of non-steroidal agents, vitamins and antioxidants, cryotherapy, laser therapy and the use of natural agents for the OM management. Concerning the use of natural agents for the prevention and treatment of OM, Santos et al. ${ }^{20}$, explain that the most cited in the literature are chamomile, aloe vera, honey and propolis.

\subsubsection{Chamomile}

Chamomile is a medicinal herb used for therapeutic purposes for many years. It is used in both scientific and popular medicine for the management of several diseases. It is a plant that contains numerous substances with antiinflammatory, antibacterial and anti-spasmodic action. Among the various varieties of chamomile, the two best known are the German (Chamomilla recutita) and the Roman (Anthemis nobilis). Chamomilla recutita is widely used due to its medicinal properties ${ }^{21}$. The most commonly used portion of Chamomilla recutita for therapeutic purposes are the floral chapters, which contain essential oil, flavonoids, coumarins, cholines, amino acids, fatty acids, mineral salts, mucilages and organic acids, and essential oil and flavonoids are the most studied agents ${ }^{17}$.

Regarding the essential oil, it has alpha-bisabolol (up to $50 \%$ ) and chamazulene (1-15\%) in its composition, in which the blue color of the oil is the result of the chamazulene composition, formed by a natural precursor during distillation. It is noteworthy that matricin consists of a compound of unstable nature and is formed by the chamazulene decomposition. Several active chemical components with biological potential of Chamomilla recutita are present in essential oil, which confers anti-inflammatory, antimicrobial and antimycotic action on this product, in addition to presenting mucosal protective mechanism ${ }^{17}$.

Its chemical constituents are grouped according to their lipophilic or hydrophilic fraction. The lipophilic portion consists of essential oil and coumarins. The hydrophilic portion presents flavonoids, mucilage, organic acids, amino acids and choline. Thus, the active lipophilic and hydrophilic principles are characteristic of the chamomile therapeutic activity $^{22}$.

The work of Braga et al. ${ }^{17}$, proposed to study the therapeutic dose of chamomile rinse for the management of OM in patients who underwent hematopoietic stem cell transplantation. As a methodology, a randomized clinical trial was performed, in which 40 patients were distributed to receive routine care and use of mouth rinse containing a liquid extract of Chamomilla recutita at $0.5 \%, 1 \%$ or $2 \%$ (experimental groups) or only placebo treatment (control group). The daily assessment of OM was carried out through the use of a measurement scale 
for oral toxicity defined by WHO. The statistical analysis evaluated the incidence, intensity and duration of OM, which were compared between each experimental group and the control group. The findings revealed that the experimental group at $1 \%$ dose showed a reduction in the incidence, intensity and duration of OM compared to the control group. The formulation was well tolerated by the patients and the dose was safe, since no moderate or severe adverse effects were identified. The study even denoted that more than half of the patients thought the use of chamomile mouthwash to be very pleasant or pleasant, and only one patient reported feeling some episode of nausea.

Whereas in the study of Reis et al. ${ }^{23}$, a comparison was made between cryotherapy performed only with water (control group, $\mathrm{n}=18$ ) and cryotherapy performed with chamomile infusion (experimental group, $\mathrm{n}=20$ ), for the prevention and reduction of OM intensity in patients with solid malignant neoplasias under chemotherapy with 5-fluorouracil and leucovorin. As for the methodology applied, this was a randomized pilot study. Both groups were instructed to shake ice around their oral cavity for at least 30 minutes during chemotherapy. Oral mucosa evaluation occurred on days 8 , 15 and 22 after the first day of chemotherapy infusion. The results obtained expressed the minimization of pain, degree and presence of $\mathrm{OM}$ in the experimental group patients in relation to the control group. With this study, it was possible to observe that there was no onset of mucositis in degree 2 and 3 in the experimental group, and all patients maintained the solid diet, compared to $94.4 \%$ in the control group. In addition, in the experimental group, there was a report of a reduction in the xerostomia sign, which represents the sensation of dry mouth.

It is important to perform mouthwash with chamomile tea for the prevention and control of $\mathrm{OM}$ in patients under antineoplastic treatment, because chamomile has a participation in the relief of symptoms and in the degree of mucositis, because of its anti-inflammatory action, in addition to the ability to inhibit the release of prostaglandins. This effect is associated with the inhibition of cyclooxygenase 2 (COX-2), which denotes that this herb has a mechanism of action similar to non-steroidal anti-inflammatory drugs ${ }^{24}$. However, it is worth pointing out that more randomized clinical trials need to be performed in this population, in order to define the therapeutic dose and ideal concentration not only of chamomile, but also of other natural agents.

\subsubsection{Honey}

Honey has been used to enable lesions healing over the years. This product can be efficient to soften wounds, burns, ulcers that affect the skin and infections in the oral mucosa. Despite the mechanisms that confer biological activity and therapeutic properties that favor the healing process, its mechanism of action is not fully elucidated yet. Honey has also been pointed out as an agent for the management of $\mathrm{OM}$ in patients submitted to chemotherapy, since it contains properties that prevent the installation of secondary infections ${ }^{25}$.

Honey has high osmolarity and high potential to create non-cytotoxic levels of hydrogen peroxide through the enzyme glucose oxidase. In addition, it also has the capacity to reduce local and plasma synthesis of prostaglandins, besides being able to increase nitric oxide levels in lesions, in a way that it accelerates the repair and healing of alterations in the mucosa, which thus minimizes the local irritations. Some recent studies have demonstrated its effectiveness in managing $\mathrm{OM}^{8,24}$.

There are several types of honey, but few have been studied for the management of oral cavity lesions. Manuka honey, which consists of New Zealand flowers, has several beneficial properties, including antibacterial, antifungal, anti-inflammatory and analgesic action ${ }^{12}$. In the study of Parsons et al. ${ }^{26}$, Manuka honey was tested in pure and diluted formulation in 28 patients with head and neck cancer submitted to locoregional radiotherapy. The results showed that diluted Manuka honey was not able to reduce the extent and installation of radiation-induced OM, however, there was an improvement in weight loss, as well as an increase in the quality of life of these oncologic patients. It is worth mentioning that six patients reported feeling nausea, vomiting and burning sensation in the oral mucosa due to the use of diluted honey, that is, this agent was not well tolerated by $21.24 \%$ of the patients.

Bardy et al. ${ }^{27}$, also evaluated the effect of active Manuka honey and gold syrup, which consists of a type of invert sugar syrup, a by-product of the sugarcane juice refining. It is found in specific locations in Europe and Africa, and to a lesser extent in North America. In radiation-induced mucositis, 131 patients diagnosed with head and neck cancer were divided into two groups (honey group and gold syrup group). It was concluded that there was no statistically significant difference between the groups on the radio-induced OM. Moreover, active Manuka honey was not able to improve OM, but both compounds were able to reduce the bacterial infections.

Hawley et al. ${ }^{28}$, proposed to carry out a study to assess the reduction in the severity of the radio-induced mucositis through the use of Manuka organic honey in cancer patients in the head and neck region. It was a controlled double-blind randomized study. A total of 106 patients were divided into two groups: experimental and placebo. The experimental group patients were instructed to swallow $5 \mathrm{~mL}$ of organic Manuka honey, four times a day during radiation therapy treatment. The control group used placebo gel, following the same protocol as the experimental group. The OM severity was graduated according to the Radiation Therapy Oncology Group (RTOG), WHO and Oral Mucositis Evaluation scale. Weight and severity of the patients' symptoms, as well as the quality of life, were evaluated weekly. Sialometry was performed at the beginning and at the last radiotherapy session. The result showed that the non-tolerance rate was $57 \%$ in those 
who received Manuka honey and 52\% in those who received placebo gel. There was no statistically significant difference between the groups in any of the result indicators. The authors evidenced that although honey may be promising, it was not well tolerated by the patients who were part of the study and, even when used according to the instructions, did not show significant impact on the severity of OM.

Song et al. ${ }^{29}$, carried out a systematic review with meta-analysis on the use of honey in radiation-induced MO management. The authors observed that there was minimization of OM in patients submitted to honey treatment. However, they stated that the data should be approached with caution, since the lack of the randomization method description and the bias potential of the three studies included in the meta-analysis could generate inconclusive results. Thus, although the results are hopeful, there is still a demand for new research to strengthen current evidence.

In a meta-analysis study by Cho et al. ${ }^{25}$, the honey efficacy in the management of OM during radiotherapy was also evaluated in patients with head and neck cancer. Randomized controlled studies comparing oral administration of honey (experimental group) with placebo or no treatment (control group) were included in patients submitted to radio or radiochemotherapy. The incidence of moderate to severe mucositis and the mean degree of mucositis during the first three weeks of therapy were significantly lower in the honey group than in the control group. In addition, the mucositis onset was significantly later in the experimental group compared to the control group. Although there were no significant differences in the incidence of microbial colonization and pain between the two groups, the incidence of weight loss was lower in the group that used honey.

$\mathrm{CHO}$ et al. ${ }^{25}$ and Hawley et al. ${ }^{28}$, agree that honey has a positive impact to prevent $\mathrm{OM}$ and loss of weight, if used regularly during and/or after radiotherapy or chemo-radiation therapy, since it has a lower cost than the agents commonly used, in addition to having minimal side effects. However, the increase in the incidence of caries in these patients was not evaluated, since honey presents sugar in its composition, which favors the appearance of caries lesions, especially in oncologic patients, who usually manifest hyposalivation and deficiency in hygiene.

Raeessi et $a .^{30}$, performed a comparison among the therapeutic effects of different agents, including topical corticosteroid, honey, and coffee-associated honey, in patients with OM. A double-blind randomized clinical trial was performed, with a total of 75 adult participants, who were randomly allocated in the three treatment groups. For all participants, a syrup-like solution was prepared. The participants were instructed to ingest $10 \mathrm{~mL}$ of the prescribed product every three hours for one week. The lesions severity was clinically evaluated before the treatment and one week after the beginning of the intervention. The results showed that all the therapeutic regimens reduced the lesions severity. The product that showed the best effect regarding the increased severity of OM was the honey group associated with coffee.

\subsubsection{Aloe Vera}

Aloe Vera, known as aloe, is a plant that has an indication in the treatment of injuries, and the most used parts for this purpose are bark and leaf. Regarding the aloe potential, it contains vitamins, minerals, enzymes, natural sugars, among other agents, which stand out for having anti-inflammatory, healing, antiseptic, antifungal and antibacterial capacity ${ }^{31}$.

Freitas et al. $^{32}$, attribute the potential anti-inflammatory effect of Aloe Vera to the presence of acemanan polysaccharide, which is extracted and isolated from the pulp of the plant leaf. Additionally, this compound has the capacity to induce macrophage growth and produce cytokines, such as interleukin 1 (IL-1), interleukin 6 (IL-6) and tumor necrosis factor (TNF), with consequent increase in phagocytic activity, which consequently improves the inflammatory response. Another mechanism of action of this plant is in the coping with inflammatory processes. According to Ribeiro e Ferreira ${ }^{8}$, with the prostaglandins synthesis, there is an increase in migration of neutrophils and leukocytes, thus there is a decrease in the concentration of TNF- $\alpha$ and other immunomodulating activities. In addition, there is a greater supply of oxygen, with consequent increase of vascularization and collagen so that healing occurs.

Mannose-6-phosphate, polysaccharide present in the aloe gel, has the ability to accelerate the healing process and the reduction of inflammation, because the connection established between manose-6-phosphate and a receptor present in the fibroblasts favor the healing mechanism. Isolated proteins and glycoproteins of Aloe Vera gel also have anti-inflammatory action because they reduce the COX-2 and lipoxygenase enzymes, similarly to non-steroidal anti-inflammatory drugs 24 .

The study by Cuba et al. ${ }^{33}$, whose objective was to clinically and histologically evaluate the effect of two types of antioxidants, vitamin E (VE) and Aloe Vera (AV), on the healing of oral lesions induced after radiation in animal model. As for the methodological procedure, the animals were randomly divided into three groups of 12 animals each (experimental group VE:400 mg VE; experimental group $\mathrm{AV}: 70 \% \mathrm{AV}$ and control group), and the euthanasias were performed in two moments, which were five and seven days after radiotherapy. The animals were irradiated with a single dose of $30 \mathrm{~Gy}$, and after 24 hours, one lesion was produced on the dorsal of each animal's tongue and the products applied daily at the same. The study showed that, in the clinical analysis, there was a higher frequency of lesions in the control group animals in the two periods. The area of lesions was also greater in the control group than in the AV and LV groups at $5^{\text {th }}$ and $7^{\text {th }}$ day, with statistical significance $(p=0.006 ; p=$ 
0.002, respectively). In microscopic analysis, the degree of inflammation differed between the study groups. At five days, the statistical difference was not significant among the groups evaluated, but at the $7^{\text {th }}$ day, the animals in the control group presented intense inflammation, while the LV and AV groups showed mild to moderate inflammation $(p=0.002)$.

Ribeiro and Ferreira ${ }^{8}$, Albuquerque et al. $^{24}$ and Freitas et al. ${ }^{32}$, agree that the anti-inflammatory effect of this agent is due to the fact that it presents the acemanan polysaccharide, which has the ability to induce macrophage growth and produce anti-inflammatory cytokines, such as IL-1, in addition to increasing phagocytic activity, in order to improve the quality of the inflammatory response. In addition, isolated proteins and glycoproteins from Aloe gel also have action in modulating inflammation because they reduce the COX2 and lipoxygenase enzymes, similar to non-steroidal antiinflammatory drugs. However, there are no studies in the literature that address this agent in the management of OM, so the results need to be carefully evaluated, because although aloe is promising, studies need to be carried out in cancer patients.

\subsubsection{Propolis}

Propolis is a natural substance with complex, non-toxic resin, collected by bees of tree shoots, flowers and plants exudate, which have antimicrobial, anti-inflammatory and healing properties ${ }^{34}$.

Regarding the propolis anti-inflammatory activity, it is known that this is due to the capacity of flavonoid compounds, which cause inhibition of COX and lipoxygenase enzymes. Furthermore, phenyl-ester-coffee acid (CAPE), which is also present in propolis, is capable of inhibiting the release of arachidonic acid from the cell membrane, in a way that COX1 and COX-2 activities are suppressed. There is also inhibition of prostaglandin synthesis and thymus activation, since the components of this agent promote phagocytic activity and stimulate the cellular immunity ${ }^{35}$. In addition to all beneficial activities that have already been mentioned, propolis also has the capacity to form epithelial tissue, to promote vascular and fibroblastic neoformation, which justifies its topical application in wounds being able to promote rapid formation of connective and epithelial tissue ${ }^{36}$.

The study by Akhavankarbassi et al. ${ }^{37}$, proposes to test the propolis efficacy as a mouthwash in the reduction of OM induced by chemotherapy. This was a randomized and controlled study, in which patients submitted to chemotherapy were allocated in two groups. The experimental group $(\mathrm{n}=20)$ was submitted to the mouth washing protocol with propolis mouth wash, and the control group $(n=20)$ was submitted to mouth washes with diluted water. OM and the ability to eat and drink were evaluated at the beginning of the chemotherapy infusion and after three to seven days, using the WHO scale and the oral mucositis evaluation scale. The result showed that there was a significant difference between the groups in the
$\mathrm{OM}$, in which the propolis group presented more satisfactory results compared to the control group, however there was no significant difference between the groups in the ability to eat and drink. It is worth pointing out that $65 \%$ of the patients in the propolis group presented complete healing on the $7^{\text {th }}$ day after the chemotherapy. No significant adverse events were reported by the patients.

Mendonca study ${ }^{38}$ aimed to carry out a survey of scientific publications on the propolis anti-inflammatory activity, its antibacterial action against microorganisms in the oral cavity, as well as to evaluate the employability of propolis as an adjuvant to the prevention and treatment of radio-induced and chemotherapy OM. The result was a review that revealed that the potential of propolis against OM is due to the association among its antifungal, antibacterial and antiviral properties, in addition to its healing and anti-inflammatory activities.

Carli et al. ${ }^{35}$ and Pinto et al. ${ }^{36}$, explained in their studies that the propolis anti-inflammatory action is related to the flavonoids ability to inhibit COX and lipoxygenase enzymes. In addition, CAPE inhibits the release of arachidonic acid from the cell membrane, which suppresses COX-1 and COX2 actions. Carli et al. ${ }^{35}$ showed that this agent also presents the ability to form epithelial tissue, vascular and fibroblastic neoformation, so it is applied topically in wounds, thus promoting the rapid formation of epithelial and connective tissue. Due to this capacity, this agent seems to be promising in the management of wounds originated from OM.

Pinto et al. $^{36}$ and Noronha ${ }^{39}$ agree that propolis has a potential in the mucositis prevention, since it is an agent with many properties that can reduce the main side effects of radiotherapy without the need to associate with antifungal agents, since propolis also presents antifungal action. In addition, it has better radiographic activity than benzydamine hydrochloride, especially in more advanced stages of radiotherapy. In addition, an extremely important characteristic of this agent is that it does not cause drug interactions, being safe for the prevention and treatment of mucositis. However, despite the multiple propolis actions, more studies related to cancer patients need to be performed and with different protocols in an attempt to obtain more conclusive results, in addition to determining the toxicity potential of this agent.

\section{Conclusion}

The constant need to develop optimal therapeutic measures for the management of $\mathrm{OM}$ has triggered studies with several natural agents that present beneficial properties in the healing process, in addition to the anti-inflammatory and antimicrobial action belonging to these compounds.

The most used natural agents for prevention and/or treatment of mucositis are honey, chamomile, propolis and aloe Vera, which has as common characteristic the induction of tissue repair, in addition to being widely accepted, since they present low cost and offer minimal interaction with other drugs. However, more randomized clinical trials need to be 
carried out in an attempt to obtain more information about the most appropriate dosage and presentation, in addition to evaluating the toxicity of these agents.

It is reinforced that the dental surgeon's action in the mucositis prevention is very relevant, since the same has the capacity to adjust the patient's oral cavity before he or she starts the chemotherapy and/or radio therapy treatment.

\section{References}

1. Figueiredo ALP, Lins L, Cattony AC, Falcão AFP. Laserterapia no controle da mucosite oral: um estudo de metanálise. Rev Assoc Med Brasil 2013;59(5):467-74. doi: http://dx.doi.org/10.1016/j.ramb.2013.08.003

2. Ribeiro ILA, Valença AMG, Bonan PRF. Treatment of severe oral mucositis in a pediatric patient undergoing chemotherapy. RGO 2015;63(4):467-71. doi: http://dx.doi. org/10.1590/1981-863720150003000143007

3. Campos L, de Carvalho DLC, de Castro JR, Simões A. Laserterapia no tratamento da mucosite oral induzida por quimioterapia: relato de caso. Rev Assoc Paul Cir Dent 2013;67(2):102-6. doi: http://revodonto.bvsalud.org/pdf/ apcd/v67n2/a03v67n2.pdf

4. Figueiredo PB, Nogueira AJ. Prevalência de neoplasias, cárie e gengivite em pacientesoncológicos pediátricos no município de Belém, Pará. Pesq Bras Odontoped ClinIntegr 2013;13(2):141-6. doi: 10.4034/PBOCI.2013.132.01

5. De Morais EF, Lira JAS, Macedo RAP, dos Santos KS, Elias CTV, Morais MLSA. Oral manifestations resulting from chemotherapy in children with acute lymphoblastic leukemia. Braz J Otorhinolaryngol 2014;80(1):78-85. doi: $10.5935 / 1808-8694.20140015$

6. Flores MP, Castro APCR, Nascimento JS. Topical analgesics. Rev Bras Anestesiol 2012; 62(2):248-252. doi: 10.1590/S0034-70942012000200010

7. Sasada INV, Munerato MC, Gregianin LJ. Mucosite oral em crianças com câncer-revisão de literatura. Rev Facul OdontolUPF 2013;18(3):345-50. doi: http://dx.doi.org/10.5335/rfo. v18i3.3338

8. Ribeiro M, Ferreira M. Compostos antioxidantes como alternativas na prevenção e no tratamento da mucosite oral induzida por agentes quimioterápicos. Rev Grad 2016;9(2);126. doi: http://revistaseletronicas.pucrs.br/ojs/index.php/ graduacao/article/view/25676/14971

9. Bensadoun RJ, Nair RG. Low-level laser therapy in the prevention and treatment of cancer therapy-induced mucositis: 2012 state of the art based on literature review and meta-analysis. Curr Opinion Oncol 2012;24(4):363-70. doi: 10.1097/CCO.0b013e328352eaa3

10. Reolon LZ, Rigo L, de Conto F, Cé LC. Impacto da laserterapia na qualidade de vida de pacientes oncológicos portadores de mucosite oral. Rev Odontol UNESP 2017;46(1):19-27. doi: http://dx.doi.org/10.1590/1807-2577.09116

11. Sonis ST. Oral mucositis. Anticancer Drugs 2011;22(7):60712. doi: 10.1097/CAD.0b013e3283462086.

12. Miranda SS, Queiroz LR, Freitas VS. Prevenção e Tratamento das Mucosites Orais: Uma Revisão Sistemática. Rev Saud Colet UEFS 2017;6(2):66-73. doi: 10.13102/rscdauefs. v6i2.1189

13. Lins RDAU, Dantas EM, Lucena KCR, Granville-Garcia AR, da Silva JSP. Aplicação do laser de baixa potência na cicatrização de feridas. Odontol Clin Cient 2011;511-6.

14. Rodriguez-Caballero A, Torres-Lagares D, Robles-García M, Pachón-Ibáñez J, González-Padilla D, Gutiérrez-Pérez JL. Cancer treatment-induced oral mucositis: a critical review. Int J Oral Maxillofac Surg 2012;41(2):225-38. doi: 10.1016/j.ijom.2011.10.011

15. World Health Organization. Handbook for reporting results of cancer treatment. Geneva: WHO; 1979.

16. Common Toxicity Criteria Manual. Common Toxicity Criteria, Version 2.0. National Cancer Institute, 1999:1-31. doi: 10.1016/s0360-3016(99)00559-3

17. Braga FT, Santos AC, Bueno PC, Silveira RC, Santos $\mathrm{CB}$, Bastos JK, et al. Use of Chamomilla recutita in the prevention and treatment of oral mucositis in patients undergoing hematopoietic stem cell transplantation: a randomized, controlled, phase II clinical trial. Cancer Nurs 2015;38(4):322-9. doi: 10.1097/NCC.0000000000000194

18. Centurion BS, Garcia AS, Rubira-Bullen IRF. Avaliação clínica e tratamento das complicações bucais pós quimioterapia e radioterapia. Rev Assoc Paul Cir Dent 2012;66(2):136-41. http://revodonto.bvsalud.org/pdf/apcd/ v66n2/a08v66n2.pdf

19. Lalla RV, Bowen J, Barasch A, Elting L, Epstein JB, Keefe DM, et al. MASCC/ISOO Clinical Practice Guidelines for the management of mucositis secondary to cancer therapy. Cancer 2014;1453-61. doi: 10.1002/cncr.28592

20. Santos RCS, Dias RS, Giordani AJ, Segreto RA, Segret HRC. Mucosite em pacientes portadores de câncer de cabeça e pescoço submetidos à radioquimioterapia. Rev Esc Enferm USP 2011;45(6):1338-44. doi: http://dx.doi.org/10.1590/ S0080-62342011000600009

21. Oliveira EL, Cabral GMP, Galvão AKFC, Pedrine JAGD, Silva MCVS, Dantas MAPD. Mucosite-uma revisão sistemática. Rev Campo Saber 2019;4(5):16-34. doi: http:// periodicos.iesp.edu.br/index.php/campodosaber/article/ viewFile/166/143

22. Lins R, Vasconcelos FHP, Leite RB, Coelho-Soares RS, Barbosa DN. Avaliação clínica de bochechos com extratos de Aroeira (Schinusterebinthifolius) e Camomila (Matricaria recutita L.) sobre a placa bacteriana e a gengivite. Rev Bras Plantas Med 2013;15(1):112-20. http://dx.doi.org/10.1590/ S1516-05722013000100016

23. Dos Reis PED, Ciol MA, Melo NS, Figueiredo PTS, Leite AF, Manzi NM. Chamomile infusion cryotherapy to prevent oral mucositis induced by chemotherapy: a pilot study. Support Care Cancer 2016;24:4393-8. doi: 10.1007/s00520016-3279-y

24. Albuquerque ACL, Pereira MSV, Pereira JV, Costa MRM, Pereira LF, Higino JS. Antimicrobial effect of Matricariarecutita Linn (chamomile) extract against Dental Biofilm Microorganisms. Pesq Brasil Odontoped Clinic Integr 2011;(10)3:451-55. doi: http://dx.doi.org/10.4034/ pboci.v10i3.1098

25. Cho HK, Joang YM, Lee HS, Lee YJ, Hwang SH. Effects of honey on oral mucositis in patients with head and neck Cancer: a meta-analysis. Laryngoscope 2015;(125)9;208592. doi: https://doi.org/10.1002/lary.25233

26. Parsons E, Begley A, Herst P. Manuka honey mouthwash does not affect oral mucositis in head and neck cancer patients in New Zealand. J Radiot Pract 2012;11;249-56. doi: 10.1017/ S1460396911000410

27. Bardy M, Molassiotis A, Ryder WD, Mais K, Sykes A, et 
al. A double-blind, placebo-controlled, randomised trial of active manuka honey and standard oral care for radiationinduced oral mucositis. Brit J Oral Max Surg 2012;50;221-6. doi: 10.1016/j.bjoms.2011.03.005

28. Hawley P, Hovan A, McGahan CE, Saunders D. A randomized placebo-controlled trial of manuka honey for radiationinduced oral mucositis. Support Care Cancer 2014;22(3):75161. doi: 10.1007/s00520-013-2031-0

29. Song TA, Twumasi-Ankrah P, Salcido R.Systematic review and meta-analysis on the use of honey to protect from the effects of radiation-induced oral mucositis. Adv Skin Wound Care 2012;25;23-8. doi: 10.1097/01.ASW.0000410687.14363.a3.

30. Raeessi MA, Neda Raeessi, Yunes Panahi, Homa Gharaie, Seyyed Masoud Davoudi, Alireza Saadat, et al . "Coffee plus Honey" versus "topical steroid" in the treatment of Chemotherapy-induced Oral Mucositis: a randomised controlled trial. BMC Complement Altern Med 2014;14(293):1-7.

31. Lima JF. As Plantas na História da dor. Rev Soc Port Anestesiol 2013;22(4):126-33. doi: https://doi.org/10.25751/ rspa.3381

32. Freitas VS, Rodrigues RAF, Gaspi FOG. Pharmacological activities of Aloe vera (L.) Burm. f. Rev Brasil Plant Med 2014;16(2);299-307. doi: http://dx.doi.org/10.1590/S151605722014000200020

33. Cuba L, Braga Filho A, Cherubini K, Salum FG, Figueiredo MA. Topical application of Aloe vera and vitamin $\mathrm{E}$ on induced ulcers on the tongue of rats subjected to radiation: Clinical and histological evaluation. Support Care Cancer
2016;24(6):2557-64. doi: 10.1007/s00520-015-3048-3

34. Pensin NR, Pensin C, Miura CSN, Boleta-Ceranto DC. Efeito de pomada de própolis em orabase para tratamento de ulcerações aftosas recorrentes - um estudo piloto. Arq Ciênc Saúde UNIPAR 2009;13(3):199-204. https://revistas.unipar. br/index.php/saude/article/viewFile/3199/2237

35. Carli AD, Zárate-Pereira P, De-Carli G, Zafalon EJ, Zárate CBR, YassumoTO LM. Ação da própolis de apismellifera associada ao fluoreto de sódio sobre o biofilme dental: ensaio clínico duplo cego randomizado. Rev Odontol Bras Central 2011;19(51):310-3.

36. Pinto LIMA, Prado NRT, Carvalho LB. Propriedades, usos e aplicações da própolis. Rev Eletronic Farm 2011;8(3);25-. doi: https://doi.org/10.5216/ref.v8i3.15805

37. Akhavankarbassi MH, Yazdi MF, Ahadian H, SadrAbad MJ. Randomized double-blind placebo-controlled trial of propolis for oral mucositis in patients receiving chemotherapy for head and neck cancer. Asian Pac J Cancer Prev 2016;17(7);3611-4. doi: 10.14456/apjcp.2016.142/APJCP.2016.17.7.3611

38. Mendonça ICG. Propolis as an adjunct to prevention and treatment of radiotherapy-and chemotherapy-induced oral mucositis. Nurs Palliat Care 2016;1;97-100. doi: 10.15761/ NPC. 1000125

39. Noronha VRAS. Gel de própolis mucoadesivo versus solução de cloridrato de benzidamina na prevenção da mucosite oral em pacientes irradiados em região de cabeça e pescoço. Ensaio clínico, cego, randomizado: fase II. 2015. Belo Horizonte: Universidade Federal de Minas Gerais; 2015. 